\title{
Intangible Culture as Tradition: The Cows' Ball, the Village Serenade and the Country Wedding in Bohinj
}

\author{
MATEJA HABINC \\ Department of Ethnology and Cultural Anthropology, \\ Faculty of Arts, University of Ljubljana
}

\begin{abstract}
The article focuses on the authenticating strategies employed by the organizers of three Bohinj events which refer to alpine grazing and wedding customs of the area. Since the beginnings of these events in the 1950s, it was largely textual aspects that were taken as contributing substantially to the authenticity of the events, whereas more recently temporal and spatial contexts of tangible and intangible culture, presented at the events, have also been taken into account. Over time the events with a mostly staged mode of performance have evolved into tradition. Nevertheless, their mode and the social aspects of the events are not perceived as intangible culture and are not part of authenticity considerations.
\end{abstract}

Key words: intangible culture, tradition, authenticity, cultural display, event tourism

In fact, the Cows' Ball is a tourist event. The whole tradition associated with it, everything labelled as "ethno" and "related to peasant life" is secondary [...] It is partially meant to construct and present the point of the event, but in reality it does not matter. The Cow's Ball is a huge tourist event, a veselica, ${ }^{1}$ a kind of holiday of Bohinj, the conclusion of the tourist season in the area. Nevertheless, I still try to incorporate some things in it, and if we look strictly from a professional point of view, nobody can say that we don't do our best. ${ }^{2}$

The Cows' Ball ("Kravji bal"), the Village Serenade ("Vasovanje"), the Country Wedding ("Kmečka ohcet") and the Midsummer Night ("Kresna noč") are la-

\footnotetext{
${ }^{1}$ An entertaining event with dancing, drinking, eating, playing games and raffle. Since the 1950 s folk music has also been its essential part (Bogataj and Godina Golija 2004: 668).

${ }^{2}$ If not marked differently, all the quotations are taken from the interview with Jure Sodja, the person in charge of the events, employed at the Bohinj Tourist Association. The interview was recorded on 15 August 2012. I use quotation marks either to mark (a part of) a statement or an expression of my interlocutor, to mark quotes or expressions from other sources or to mark exact names (e.g. of a project). The expressions or names which are not translated but explained in footnotes are written in italics.
} 
belled as traditional events by their organizer, the Bohinj Tourist Association, which was one of the leadning tourist associations in Slovenia until 1998. ${ }^{3}$ Yet, according to informal discussions with some of my work colleagues and in my opinion as well, all four of them seem to be the kind of events that (Slovenian) ethnologists or anthropologists would often avoid attending. One part of the answer as to why this is so could be that these events take the form of a veselica, which is usually associated with specific music and socializing which is a matter of personal taste. However, regardless of the reasons, I find it problematic that lately these events have not been sufficiently analysed and researched (with some exceptions, see for example Poljak Istenič 2005 and Klobčar 2012). Perhaps this is also due to the organizers' or public expectations about an ethnologist - seen as a professional who is thought to possess the greatest and the most thorough knowledge of tradition and is thus able to judge whether and in what way a specific event is truly traditional (cf. Poljak Istenič 2008: 75). As such events have long been recognized as examples of folklorism (cf. Ceribašić 2008: 259), one can find him/herself in a pickle when trying to distinguish folklore from folklorism (taken as two theoretical extremes). This position of a judge is therefore quite unpleasant. But similarly, as was pointed out decades ago, research can rather turn its focus to all the processes between these two theoretical extremes and to the phenomenon itself (Rihtman-Auguštin 1978: 25). And this is exactly the focus I had when researching the three events in Bohinj.

Since the very beginnings of these events, i.e. almost six decades ago, these events were conceived as cultural displays, ${ }^{4}$ and their organizers were concerned with how to present the tradition they were referring to. The traditionality of the events has been recognized in their long-lasting continuity, as well as in their contents. As I will elaborate, both of these elements can be considered intangible culture - a performance of the events together with the mode of their organisation as well as alpine grazing itself, marriage customs and the local dialect as those elements to which the events usually refer. They are all parts of human creativity, but according to the organizers, a performance of the events, the mode of their organisation, alpine grazing, marriage customs and the local dialect are not equally recognized as intangible culture ${ }^{5}$ nor are they all equally related to tradition. Thus, the article will primarily focus on the organizers' perception and evaluation of tradition associated

${ }^{3}$ At that time, new legislation on fostering tourism was adopted in Slovenia (Bajuk Senčar 2005: 98), which reduced the strenght of the association to some extent.

${ }^{4}$ Non-ordinary, framed, public events requiring participation, in which actions and objects are invested with meaning and values are put "on display" (Abrahams 1931: 303).

${ }^{5}$ I consider it a process of human creativity of the past and the present in the widest sense, implying possibility of transformations (cf. Nikočević 2012: 7, 9). By stressing contextual aspects it is inseparable from the material or tangible culture of, for instance, alpine grazing, which is sometimes emphasised in the article by a joint usage of both notions (tangible and intangible culture). 
with the events. Furthermore it will deal with the fact that authenticity is not only a fiction ${ }^{6}$ but also a reality, because it is the foundation of the organizers' discourse, and as such a social fact, affecting social practice (Ceribašić 2008: 261-262). I will illustrate how perceptions and evaluations of tradition have varied from case to case and over time, and what they have been subjected to. With regard to this, I will focus on the organizers' justifications of the changes to the events. All in all, the article will mostly speak about intangible culture and perceptions of tradition, about authenticity as an aesthetic conception and contemporary practice, relying on imagined practice from the past (Kaschuba in Ceribašić 2008: 262). Reflection on my own research will be implicitly included. Analysing my interview with the representative of the Bohinj Tourist Association, I kept asking myself (however rhetorically) what would have our meeting been like if I was not perceived as an ethnologist in the first place. During our talk I was constantly faced with the general perception of the profession which is supposedly not only specialised in tradition but also in its preservation. It is also not negligible that I met my interlocutor as a member of a research team, working on the research project "The Triglav national park: heritages, actors, strategies, questions and solutions". This project (July 2011 - June 2014) is financed by the Slovenian Research Agency, and focuses on heritages (whatever one has in mind when using this word), ${ }^{7}$ or more importantly, on various actors, strategies and questions of the contemporary situation in the only Slovenian national park, while its main goal is also to find solutions for these issues. During our conversation I therefore got the impression that I was not only perceived as an outsider, a representative of the profession, but also as an individual who has the authority and the legitimate role to mediate among various actors in the area. It seemed that personal perceptions and intentions of the representative (and) of the association were very carefully presented: he spoke to me as the legitimate representative of the local tourist association. Yet, according to his self-presented biography, he, too, is an outsider, although he has relatives and recently also a wife in the area. He is also an experienced tourism employee, while in his spare time he is also an individual with many hobbies - e.g. he is the leader of a local cultural association with a folklore

\footnotetext{
${ }^{6}$ Authenticity as the supposedly basic value of folklore - which can in my opinion also be applied to tangible and intangible culture - is a fiction, since it is imagined as almost unvarying practice from the past. As explained for the Croatian context, it usually refers to the folk culture from the second half of the 1930 s, rural environment and antiquity, to something domestic and clean with no foreign influence, to something collective, unprofessional and Croatian (Ceribašić 2008: 260).

${ }^{7}$ In the article I mostly write about tradition, since this is a term that my interlocutor and the majority of other sources also used. By relying on the emic expression I also follow the distinction, although just one of many, by which tradition is something that everybody desires to talk about, while heritage is limited to professional debates (see Brumen 2001).
} 
section. And members of this folklore section collaborate in at least some of the events presented in this article. I wonder whether his personal affinity for local folklore ensembles, together with general perceptions of ethnology as a profession have somehow influenced the way he presented the notions of intangible culture and tradition. Probably yes, but how have they recently affected the Cows' Ball, the Village Serenade and the Country Wedding? ${ }^{8}$ To address this question, let me begin with some historical information which I gathered by reviewing archival data and periodical sources, ${ }^{9}$ by attending the events in 2011 and 2012 and by conducting interviews with Jure Sodja, a representative of the Bohinj Tourist Association, who gave me an insight into the contemporary situation.

\section{LIKOF, ${ }^{10}$ A PARADE OF NATIONAL COSTUMES AND LOCAL RIVALRY AS THE STARTING POINT}

In the years between the two World Wars, the ending of a grazing season in the Bohinj area was marked by a social gathering of farmers and shepherds in a local pub. Around 1925 this practice joined with caterers' celebration of the closing of the main tourist season (Šilc 2010: 6). Back then tourism was already a developing economic activity in the otherwise mainly agricultural alpine area of north-western Slovenia. However, in the socialist post-SecondWorld-War-years tourism was supposed to become a massive and amateurishly sustained activity (Hofman 2009: 298). It was then that this internal social gathering became a general reference point of departure for the local tourist association. Its efforts to organize the event, named the "Traditional Cows' Ball", were also supported by the initiative of the representative of a national tourist board (1953-1.pdf: 7). It was in 1954 that the Cows' Ball was

\footnotetext{
${ }^{8}$ Due to many reasons, but mostly because the event of Midsummer Night only refers to Midsummer in its name, I left it out of my research.

${ }^{9}$ As part of the course Rituals of Slovenia offered at the Department for Ethnology and Cultural Anthropology at the Faculty of Arts, University of Ljubljana in the academic year 2012-2013, students reviewed the archival recordings of the meetings of the board of the Tourist Association of Bohinj had in the years 1946 to 2006 (see: http://www.bohinj-info.com/si/turisticno_drustvo_bohinj/organi/ zapisniki.html). I have taken their findings into account and have also checked the same archival sources for the period 1946-1960 and 2008-2012. For the years between 1978 and 2010 (with the exclusions of 1986 and 2008) the students also checked the newspaper "Gorenjski glas", issues published in June, July, August, September and October. In addition to their findings I have also reviewed the same newspaper, published in July, August and September from 2001 until 2011 and tried to follow other media reports on the events in the same period. In this article the names of archival, web and periodical sources are shortened, while in the list of references they are written in full.

${ }^{10}$ Likof is a general term for an internal social gathering, usually with food, drinks, possibly also with music, singing and dancing, a festive way of concluding some work (cf. Godina Golija, Ložar Podlogar and Simič 2004: 285).
} 
organized as a massive tourist event for the first time, and a cow procession from the mountain pastures was presented as its central event, its highlight (cf. 1955-12.pdf: 2 and 1956-6.pdf: 2). The cow procession was followed by the evaluation of the herds and by presenting awards to the most diligent farmers (1954-1.pdf: [1]). It was as early as 1962 that the event was strategically moved from the area around the Zlatorog hotel in Ukanc ${ }^{11}$ to the nearby meadow across the Savica river, where it is still performed today. This has simplified the traffic and parking arrangements and has also ensured that the visitors pay the entrance fee for the event (1962-5.pdf: 1). Herding the cows from the mountain pastures began to be staged at approximately the same time. The organizers started to pay farmers to take their cattle to the event as if they were coming from the mountain pastures (1960-3.pdf: 1). According to the organizers' interpretation, the farmers were thus "promoting" the event (1961-15.pdf: 2).

A similar model of modernization (cf. Kockel 2002: 168 and Bendix 1989) can be traced in the case of the two other contemporary tourist events, promoted as the most traditional ones in Bohinj, the Village Serenade and the Country Wedding. In the 1950s the president of the local tourist association, who had been cooperating with his predecessors since 1932, proposed to organize an event that would include a parade in national costumes and that could be presented as the (supposed) continuation of the Peasants' Feast, which took place in villages around Bohinj in 1939 and in 1946 (1955-2.pdf: 1; see also 1955-8.pdf; Dobravec 2000: 7; Stare 2007: 7). Another model was the Country Wedding performed in the neighbouring rival tourist town of Bled. As part of the celebrations connected with the Bled Municipality Day in 1955 "national costumes and folklore groups" were presented and judged (1955-13.pdf: 1). ${ }^{12}$ In 1955 "Kmečka ofct"13 was organized in Bohinj for the first time, to mark the beginning of the tourist season and to complement the Cows' Ball at the end of the season (1955-2.pdf: 1). The scenario of the Country Wedding was made with the assistance of Tončka Marolt, the musical leader of the France Marolt Academic Folklore Group, who had also been the leader of a folklore group attached to the Bohinj Tourist Association at one time (KD Bohinj). ${ }^{14}$ This was supposed to ensure a "correct and true"

${ }^{11}$ One of the villages surrounding the Bohinj lake, where the Cows' Ball has been organized since its beginning.

${ }^{12}$ A folklore group, a section of the Tourist Association of Bohinj, also participated in the Country Wedding in Bled in 1954. But the rivalry among the towns had existed before. For example, in 1947 the Peasants' Feast was also organized in Bled, which was the reason that a similar event was cancelled in Bohinj, since it had the same name, contents and was supposed to be performed on the same day (1947-6. pdf: 1; cf. 1947-8.pdf).

${ }^{13}$ A name for the Country Wedding in the local dialect.

14 The Academic Folklore Group was named after Tončka Marolt's husband, France Marolt, the founder of the Folklore Institute in Ljubljana (1955-13.pdf: 1; cf. Ramovš 2004: 310; Ramovš and Slavec Gradišnik 2004: 309-310). 
performance of the event which was divided into two parts: "a play on the eve before the Country wedding to present customs - old peasant customs related to their everyday life - national customs [...] and on the next day a parade with wagons from Stara Fužina, which would firstly present local attractions (handicrafts from Bohinj) and would then head towards the spot Pod Skalco where a veselica with its program would ensue" (1955-2.pdf: 1-2; cf. Šilc 2010: 37).

However, it was not before the beginning of the 1960s that the scenario of the Country wedding became more or less fixed (1961-7.pdf: 1; cf. 1961-21. pdf: 1). ${ }^{15}$ Since then, the Village Serenade has remained a Saturday or Friday evening play which presents customs, related to the marriage proposal, which is no longer followed by a feast. The Country Wedding was opened on the second day, with a parade featuring the members of the local folklore group wearing national costumes, representing wedding guests, the bride and the groom. Various wedding customs were presented in the parade which stopped in several villages along the way and eventually only the conclusion of the programme and the feast still took place at the same spot as the Village Serenade.

In the beginning, the Cows' Ball, the Village Serenade and the Country Wedding were thus public, tourist events and innovations, based on how the organizers imagined some related events from the past (i.e. before the war). They either referred to a social gathering of farmers, shepherds and caterers or to a local Peasant Feast - an event which aimed at building regional and national consciousness. Moreover, it was also local rivalry with the neighbouring tourist town of Bled that contributed to the Country Wedding of Bohinj. The formulas of all three events (once taken to be and promoted as only two), which had not changed much until recently, seem to have resembled each other: all three events built on the image of their traditionality even in their name ("Traditional Cows' Ball" and "Kmečka ofct") and for decades all of them were also constructed as outdoor massive presentations of authentic although vanishing tangible and intangible local culture. They presented alpine grazing and wedding customs in the local dialect, which were conceptualised as "national goods" at the time (Lozica 2009: 281) and presented as cultivated and staged. This cultural part of the programme primarily provided "propaganda" for the development of massive tourism in the area, and no matter how much criticism was addressed

${ }^{15}$ The staged Country Wedding narrowed down to the wedding customs, folk songs and dances of the area. Plans for the Country Wedding in 1955 for example included: "construct an old kitchen/house in Stara Fužina - to display all the old implements for dairying and cheese-making [...] all the old customs of Bohinj should be displayed, an exposition of handicrafts should also be prepared [...] The event should stage the real image of the old genuine Slovene customs - scenes from the life in Bohinj" (1955-2.pdf: $1-2)$. 
at the (uncultivated) part of the entertainment, it has been prevailing since the very beginnings of the events. ${ }^{16}$ Still, according to the organizers they kept trying to improve the scenarios of the events: for example, as early as the middle of the 1960s they considered including a real marriage ceremony into the Country Wedding of Bohinj (1966-12.pdf: 2). At that time, such practice was already present at least in the Slovenian capital, Ljubljana (Poljak Istenič 2005: 132) and in the rival tourist town of Bled, whereas in Bohinj it was not before 1993 that it was realised for the first time - when Slovenian tourism was on the decline and the Country Wedding in Bled was no longer performed. The Bohinj Tourist Association seized the opportunity and not only organized "the oldest" but also "a true" Slovenian Country Wedding (as often promoted today), which included a real civil and religious wedding ceremony (1994-9.pdf: 1-2). According to the media reports of the time, a real wedding gave the Country Wedding of Bohinj "new energy" after decades of the event being only performed (Lotrič 2008: 24) which allowed keeping its audience massive in the later years. ${ }^{17}$ On the other hand, the scenarios of the Village Serenade and the Cows' Ball, which were still massive occasions in the 1990s and almost until recently, have not changed much.

\section{TRACING "ETHNOGRAPHIC ADEQUACY": TEMPORALITY, LOCATION AND STAGING}

No matter how the accompanying programme has changed over time, herding the cows, enacting the Village Serenade and presenting wedding customs in a parade as well as on stage have remained the core of all three events for decades. In the organizers' opinion the scenes of the Village Serenade and the Country Wedding have also been shortened to the most crucial ones, while at the same time they have become "more fun and thus performed more smoothly". However, in the first years of the new century the organizers (who nowadays claim to be often accused by other organizers and tourist workers of being a profitable enterprise rather than a voluntary civic association)

\footnotetext{
${ }^{16}$ For example, compare the criticism of behaviour at the Country Wedding from the mid 1960s: "many have observed national costumes and the whole parade of the Country Wedding as a kind of the carnival masquerade. We can understand this, since today we only value what is considered modern [...] However, foreign guests were extremely satisfied. They were well taken care of and they were able to take photographs and movies from up close" (Šemrl 1964).

${ }^{17}$ For example, in 2003 the Country Wedding in Bohinj hosted over 100 wedding guests and 20.000 visitors (Škrjanc 2003: 21). The Tourist Association of Bohinj always tried to motivate couples for the wedding both financially and by offering gifts. As my interlocutor explained: "If you calculate a bit, it still takes at least five thousand euros to organise a wedding. So, however you put it, at least financially and socially many couples and their parents are still interested in having such a wedding" (cf. Škrjanc 2003: 21; Škrjanc 2004: 1).
} 
started to complain that traditional events are nothing but a cost to them (2008-5.pdf: 4). What was particularly questioned was how justified it is to continue the Village Serenade and the Country Wedding, since both started to lose their audience ${ }^{18}$ and more or less turned into partying occasions for their performers, thus being "far from cultural events":

The route of the Country Wedding started in the village of Češnjica, where the performers began drinking [...] Tourists followed the parade, driving their cars and thus always arriving late to the programme [...] Then, there was drinking again everywhere where the parade stopped, so the performers arrived to the stage at Pod skalco already really drunk! While there were only a few tourists around [...] Those mostly came to the party at Pod skalco in the evening, where the last act of the Country Wedding was staged, asking themselves what all the stir was about.

Nevertheless, the decision to keep all three events, which was supported primarily by the oldest members of the Bohinj Tourist Association, was made due to the realization that "the three basic traditional events are so important that it is necessary to preserve and further develop them" (20088.pdf: 2-3). This was similar to how, during the post-war period, tradition was primarily perceived in terms of the longevity of the events, which could contribute to their recognition and promotion. Content-wise tradition also seemed to be perceived as disappearing tangible and intangible culture of the area and although "strong locomotives of socialist progress" undermined the politically unsuitable past, this tradition was supposed to be at least symbolically recognized (cf. Lozica 2009: 281). In my opinion, a new shift has recently appeared: while intangible culture related to the Village Serenade and the Country Wedding kept its predominantly symbolic role, tangible and intangible culture of alpine grazing is no longer recognized merely on the symbolic level. It is being promoted as something that society could return to and learn from, something to base its contemporary development upon. Consequently, tangible and intangible culture of alpine grazing seems to be regaining its economic value and the Cows' Ball is often promoted as an opportunity for people's re-employment or at least additional income: "the Cows' Ball intends to present cattle-breeding to the youngsters and perhaps even inspire them to become shepherds,' Jure Sodja from the Bohinj Tourist Association explained" (Rant 2009: 24). ${ }^{19}$ Similarly, today the organizers of

${ }^{18}$ In 2005, the Country Wedding hosted two thousand visitors and a couple of hundred in the next year (Škrjanc 2005: 4; Stanovnik 2006: 4).

${ }^{19} \mathrm{Cf}$. the statement by the Mayor of Bohinj: "We need to make sure that people return with their cattle to the mountain pastures and thus maintain the longstanding tradition alive."' (P. L. 2007: 4). Since 2009 the only Slovene "autochthonous beef breed, cikasto or the beef of Bohinj" is also presented and evaluated at the Cows' Ball (see for example 2009-7.pdf: [19, 23-24]). 
the Cows' Ball try to incorporate some marginal or complementary economic activities "which fit the environment" into the event, such as cattle-breeding, forestry and crafts. ${ }^{20}$ But what does this say about the organizers' perception of tradition? The way I see it, they seem to perceive the pre-socialist period as the exclusive time of tradition to which their notion of an "ethnographic adequacy" is also connected. They used this notion as a marketing label for describing whether or not an element of an event fits into their image of fictionally authentic tangible or intangible culture, for example alpine grazing. Here is one of their "smart marketing moves" to illustrate their reasoning: "we have agreed not to sell ćevapčići at the Cows' Ball, since ethnographically they do not fit the occasion" (Štruc 2011: 4). So, if the tradition refers only to the pre-socialist times and activities, then it is not acceptable to sell ćevapčići $i^{21}$ at the event. Since ćevapčići have been perceived as the most common food of public (massive or not) and private gatherings in the (post)socialist Yugoslavia, they cannot be compared with the "traditionally" produced food of the Bohinj area, such as, for example, the Bohinj cheese, žganci ${ }^{22}$ and Kranjska sausage, the sale of which has recently been encouraged at the Cows' Ball (see for example Rant 2009: 24; Štruc 2011: 4).

While the pre-socialist period and activities play an important role in imagining "ethnographic adequacy", the organizers also connect the notion with a proper "traditional" location, which resulted in some recent changes to the events. The Village Serenade and the Country Wedding were at first conceived as a single event which was later split into two parts, having at least their final acts performed at the same spot. These two events, which are separate today, were also recently moved to new locations in two smaller villages near Bohinj. Initially, in 2009, the Village Serenade was moved from the area at Pod skalco to the square in the centre of the village of Srednja vas (2008-8.pdf: 2-3), which, according to the organizers, offered a "true" and "not so fake" venue for the play: "The play is not drawn out so that you go to sleep, it is not something uptight and stiff, it is effortless, you can also see the performers very well. They are more exposed and aware of that, which stimulates them to try even harder [...]. And that setting, that balcony! And that fountain under the linden tree!" This relocation was in part encouraged by the denationalization of the Pod skalco area, ${ }^{23}$ which had more positive

\footnotetext{
${ }^{20}$ For example, since 2005 a part of the Cows' Ball has also been an exhibition, entitled "LesEnDemo", where contemporary possibilities of using wood for heating have been presented (Zaplotnik 2008: 18; 2009-7.pdf).

${ }^{21}$ Grilled rolls made of minced meat (Bajec et al. 1994: 101).

${ }^{22}$ A dish cooked by pouring flour into boiling water or by pouring boiling water over roasted flour, creating a lumpy mass. Žganci prepared from various sorts of flour were a common peasant dish in the 19th and in the first half of 20th century (Makarovič 2004: 721).

${ }^{23}$ After the Second World War the area was nationalized and The Tourist Association of Bohinj, even though there was no legal basis for it, became its manager. Gradually the association built and hired some
} 
than negative consequences in the organizers' opinion: "This arrangement enabled us to attract a true audience which came to see the play [...]. If the Village Serenade had so far had a lukewarm reception, it wasn't the case this year, and the event could be considered a success" (2009-7.pdf: 23-24). It was also a success financially, since the Village Serenade became "an intimate" and low-cost "true ethnographic" event, "displaying life as it was" in a re-cultivated manner. This means all entertainment either vanished or was transformed into an after-party for the performers in a nearby pub. They find the Village Serenade an important part of their folklore performances, but in the words of the organizer they also enjoyed partying and thus resisted moving the event to the new location which restricted it. Similarly concerned about its sociability aspect, they were also not enthusiastic about changing the Country Wedding a few years later. Until 2012 the event was performed the way it had been designed in the 1960s, however, the interest for the event has recently been small (see for example 2010-7.pdf: 19-20). In 2012 the Country Wedding was thus moved to the village of Nemški rovt, where it was appended to the 90th anniversary of the local firefighter brigade. Joint organization was not only a way of saving money for the Bohinj Tourist Association, but it also made some organisational procedures easier. Furthermore, following a break of several years, another real couple got married on the occasion. A parade of people wearing national costumes performing marriage customs went through a part of the village, and the "cultural programme" was followed by a veselica for the wedding guests and the audience. Just like in the case of the Village Serenade, the organizers rationalized the relocation of the Country Wedding primarily by referring to the authenticity of the setting: "the main point was that we went to the countryside" where both events had "originally been taking place". This does not imply that the village of Ribčev Laz, where the Pod skalco area is located, has become urbanized over the years. Nevertheless, it does reflect the (not only contemporary) idea about which part of Bohinj represents the centre of tourist activities and has the corresponding infrastructure. Moving financially exhausting and, at least according to the organizers, poorly attended events to its spatial margins thus only signifies that the two events got a marginal status. This did not only happen in the eyes of their organizers, but above all in the eyes of the audience which was no longer as large as in the past. By moving the Village Serenade and the Country Wedding to the periphery, based on the idea of "ethnographic adequacy", the organizers

buildings there (2009-5.pdf: 4). In 2012 the Archdiocese of Ljubljana regained partial ownership of the area, which could not be registered in the land registry, since the illegally built constructions of the Tourist Association had to be taken down first (2012-26.pdf: [4]). 
perhaps also tried to rekindle interest in the events, if not among the tourist masses, then at least among a smaller, "true" audience.

Furthermore, enactment seems to be yet another aspect of the organizers' focus when conceiving of the "ethnographic adequacy" of an event. However, relating "ethnographic adequacy" to the tradition of enactment seems to cause the greatest ambiguity. For decades the Cows' Ball, the Village Serenade and the Country Wedding displayed culture mostly in a staged manner (e.g. herding the cows), however more recently the adequacy of staging is strongly related to the perception of objective authenticity (cf. Bendix 1997: 188-218) and questioned, depending on the type of event. For instance, a staged cow procession is perceived as a drawback of a "huge tourist event". The conversation with my interlocutor ended as soon as we started talking about the possibility of a real, unstaged event of herding cows: "No way. You can't make it." It is also interesting that the organizers (as well as the media) discursively hide staging as a kind of a public secret. The reports from this, still massive event, ${ }^{24}$ could for example be quite misleading: "'Today we arrived from the mountain pasture of Blato directly to Ukanc. I have been coming to the Cows' Ball for as many as twenty-five years, and before that my father had also been coming here. I also brought with me the old dairy equipment which belonged to my great-grandfather [...],' the shepherd Jože Cerkovnik from Ukanc reported" (Štruc 2011: 4). On the other hand, questions of whether herding cows is "for real" or not does not seem to preoccupy the visitors of the event, who, it was my impression at least, consider the staged act of herding cows as the main attraction of the Cows' Ball and its tradition. While enactment/staging is perceived as a deficient model only in the case of mass events, the organizers find it acceptable in the case of intimate events. For example, they realize that a real wedding means "a different motivation and energy", a better starting point for the promotion of the Country Wedding, while it also causes higher costs and a higher responsibility when "playing with the real fates of two individuals". A staged wedding is thus considered safer and less challenging, yet is still at least an aesthetically interesting "cultural" event where "people are interested in taking pictures of the parade". A special terminology to describe such events was also used: "The ethnographic event is never about going on a drinking spree. An ethnographic event always presents and stages something [...] It is a performance. A performance which is in a way even more original. Which should protect traditional habits, language [...] which should present something that once happened here". As illustrated above, the Village Serenade and the Country Wedding are conceptualised as "ethnographic events", while

${ }^{24}$ For example, in 2003 and 2004 the Cows' Ball hosted approximately 6000 visitors (Škrjanc 2003: 1; Škrjanc 2004: 21). 
the Cows' Ball fits into a different category, that of a "huge touristic events". Nevertheless, although both categories contain the idea of traditionality, each follows a different set of criteria as to how to apply and present tangible and intangible culture.

\section{"ETHNOGRAPHIC ADEQUACY" AS A WAY OF PROFILING AND/OR GIVING MEANING TO THE EVENTS}

Why and how can all three events be presented as traditional is a question their organizers have been dealing with since their beginnings. However, over time their answers have partially changed. Right from the start traditionality has been focused on the (at least imagined) longevity of the events and has also served as a marketing strategy (cf. Poljak Istenič 2008: 71). On the other hand, tangible and intangible culture of alpine grazing, marriage customs and the dialect, presented as the "point" of the events, were also understood as tradition implicit to the events. In the 1950s, the main focus was thus directed towards the scenarios and texts of all three events, and when the events largely turned into entertainment, their texts were shortened and "made lighter". Over time, enactment as the model for the events also came into question, for example in the 1990s when a true wedding ceremony was considered and incorporated into the Country Wedding. However, especially in the last decade when the organizers strived for "ethnographic adequacy" of the events, the focus has also turned to the context, for example to the time-frame, the location and (still) to the staging as well. Texts or contexts of the alpine grazing, marriage customs and the dialect, presented as the "point" of the events, have thus always been in the forefront of the organizers' concerns. Other aspects of intangible culture (e.g. the events themselves being cultural displays as post-modern traditions (Kockel 2007: 25; cf. Ceribašić 2008: 269) or enactment as the model of the event) were usually left aside. Nevertheless, as I have already mentioned, visitors of the Cows' Ball consider the staged cow procession the highlight of the event. Moreover, social aspects of the intangible culture presented by the events, or the social culture of the events themselves, have rarely, if at all, been in the forefront of the organizers' concerns. They have mostly been concerned with the question of who the events are organized for, and since (both economic and social) interest of the visitors and the locals in their "local pride"25 has been gradually vanishing (cf. Klobčar 2012: 168), the Village Serenade and the Country Wedding have

25 “The Cows' Ball. Look, we pay for everything: for the land, for security, for music, for the people who work, for tent rental, the stages, medical assistance, fire-fighters [...]. If I'd ask people to bring their cows for free, we wouldn't have a single cow at the event [...]. No, there is no more pride left." 
changed their purpose/target group over time. At first they were occasions for both the outsiders and the host community, over the years they turned into parties primarily for the hosts and the performers, and more recently they have again turned into occasions primarily for the outsiders:

In other places where events like the Country Wedding are organized, the locals interconnect. They prepare everything, clean in front of their houses, nobody has to ask them to do anything, nobody has to delegate what has to be done or offer them loads of money in return [...] and here I can't find a hundred people willing to come proudly to such an event [...] Therefore, this year I went to prepare the Country Wedding in a village where people cooperate and make things happen [...] When, for example, the event started in Srednja vas [...] people didn't care about it.

On the other hand, the Cows' Ball, as a massive and economically viable event, still attracts performers as well as the audience. Still in the attempt to examine all three events, which "have contributed an important share to the cultural identity of Bohinj, the way it is presented to the tourists" (Bajuk Senčar 2005: 96), and to find reasons why the interest for the Village Serenade and the Country Wedding have vanished, Handelman's definition of events-statements (Handelman 1990: 94) proves useful. According to Handelman, events-statements produce a specific static image about the intangible culture of the society as well as of its moral order, by which social control is preserved and the attention is withdrawn from the conflicting social condition (Handelman 1990: 94). For example, the Village Serenade and the Country Wedding have been organized right from the beginning with the aim "to present a part of our tradition, culture, language and history in the magnificent ambience [...]; they are mostly about preserving customs and language" (2009-7.pdf: 24). ${ }^{26}$ As such they are perceived as "ethnographic" or "cultural events", "enactments" and "never binge drinking", which is an idea and image that was ascribed to the tradition already in the 1950s when the events were organized for the first time. Back then, the organizers tried to (symbolically) preserve such tradition as a "national wealth", which gave way to novelties (Lozica 2009: 281). But when preserving tradition is considered today or when tradition is even presented as a point to return to, the organizers also have second thoughts about it. It all seems that the contemporary Cows' Ball goes hand-in-hand with post-modern consumerism, entertainment and even with the ethno-eco-edu trends (cf. Klekot 2010), while the Village Serenade and the Country Wedding regained their national (or at least regional) appeal in the 1990s. However they soon started to turn into

${ }^{26}$ Or: "The meaning of the event is to transfer customs to the youngsters and to preserve the local dialect" (Lotrič 2008: 24). 
exoticism: already in 2003 the couple, who later did get married in Bohinj, had been considering options, whether to "marry in Africa or at the Country Wedding" (Škrjanc 2003: 21). And as the current situation implies, at least for the audience, such an attitude has not changed much. This may also be due to the fact that the decision to preserve the three traditional events was mostly arrived at under the influence of the oldest members of the Bohinj Tourist Association as their opinion-makers. In contrast, the decisions of how to preserve the events, what to conceptualise, display and present as tradition and at the same time how to avoid causing too much of a financial fiasco were largely left to the person in charge of the events. He is employed at the Bohinj Tourist Association and acts as a one-man band. He combined the willingness to preserve the tradition of the events (for tradition's sake) with his role as the leader of the local cultural association with a folklore section. Thus he introduced some changes he found economically justifiable, which corresponded to his perceptions of intangible culture, traditionality and "ethnographic adequacy". Those perceptions consist of alpine grazing, marriage customs and the local dialect as intangible culture, whereas the performance of outdoor (massive) presentations, their specific mode of enactment in a cultivated staged manner and various social aspects (of the events themselves and of the intangible culture they present) is something that is not perceived as intangible culture. Nevertheless, at least in my opinion, they are also part of the historical process of human creativity, inspired by regional and national endeavours and supported by tourism as well as by the (socialist or capitalist) ideology. These events seen as cultural displays have been undergoing a transformation. However, enactment, regardless of the fact that the organizers question its "ethnographic adequacy", has remained a part of the creativity, which is recognized by the audience as something specific to the events; as events-related tradition. Therefore I support the claims (cf. Kockel 2007: 25) that we can consider such cultural displays intangible culture especially because of their specific mode of enactment.

\section{REFERENCES CITED}

Abrahams, Roger D. 1981. "Shouting Match at the Border. The Folklore of Display Events". In "And Other Neighborly Names". Social Images and Cultural Image in Texas Folklore. Richard Bauman and Roger D. Abrahams, eds. Austin: University of Texas Press, 303-321.

Bajec, Anton et al. 1994. Slovar slovenskega knjižnega jezika. Ljubljana: DZS.

Bajuk Senčar, Tatjana. 2005. Kultura turizma. Antropološki pogledi na razvoj Bohinja. Ljubljana: Založba ZRC, ZRC SAZU.

Bendix, Regina. 1989. “Tourism and Cultural Displays. Inventing Traditions for Whom?” The Journal of American Folklore 102/404: 131-146. [http://dx.doi.org/10.2307/540676]

Bendix, Regina. 1997. In Search of Authenticity. The Formation of Folklore Studies. Madison, London: University of Wisconsin Press. 
Bogataj, Janez and Maja Godina Golija. 2004. "Veselica”. In Slovenski etnološki lekiskon. Angelos Baš, ed. Ljubljana: Mladinska knjiga, 668.

Brumen, Borut. 2001. "Umišljena tradicija 'dobrih starih časov'”. In Zemljevidi časa. Zmago Šmitek and Borut Brumen, eds. Ljubljana: Oddelek za etnologijo in kulturno antropologijo, Filozofska fakulteta, 193-207.

Dobravec, Ludvik. 2000. 50 let bohinjske folklore. Bohinjska Bistrica: TD Bohinj.

Ceribašić, Naila. 2008. "Folklor i folklorizam". In Predstavljanje tradicijske kulture na sceni i u medijima. Aleksandra Muraj and Zorica Vitez, eds. Zagreb: Institut za etnologiju i folkloristiku, Hrvatsko etnološko društvo, 259-270.

Godina Golija, Maja, Helena Ložar Podlogar and Vladimir Simič. 2004. "Likof”. In Slovenski etnološki leksikon. Angelos Baš, ed. Ljubljana: Mladinska knjiga, 285.

Handelman, Don. 1990. Models and Mirrors. Towards an Anthropology of Public Events. Cambridge et al.: Cambridge University Press.

Hofman, Ana. 2009. "Performing Modernization. Socialist Culture Policy and Folklore Manifestations in Serbia." Revue des études Sud-est européennes 47/1-4: 293-313.

KD Bohinj. Available at: http://www.kdbohinj.si/odrasla_folklorna_skupina.php (accessed 2 May 2013).

Klekot, Ewa. 2010. "The Seventh Life of Polish Folk Art and Craft". Etnološka tribina 40/33: 71-85.

Klobčar, Marija. 2012. "Ritualism as a Reflection of Social Transformation and the Researcher's (Lack of) Power”. Traditiones 41/1: 159-174. [http://dx.doi.org/10.3986/Traditio201241011]

Kockel, Ullrich. 2002. Regional Culture and Economic Development. Explorations in European Ethnology. Aldershot et al.: Ashgate.

Kockel, Ullrich. 2007. "Reflexive Traditions and Heritage Production". In Cultural Heritages as Reflexive Traditions. Ullrich Kockel and Máiréad Nic Craith, eds. New York: Palgrave Macmillan, 19-33.

Lotrič, Petra. 2008. "Prava kmečka ohcet”. Gorenjski glas, 29 July 2008: 24.

Lozica, Ivan. 2009. "Traktat o prioritetama”. In Izazov tradicijske kulture. Svečani zbornik za Zoricu Vitez. Naila Ceribašić and Ljiljana Marks, eds. Zagreb: Institut za etnologiju i folkloristiku, 272-291.

Makarovič, Gorazd. 2004. "Žganci”. In Slovenski etnološki leksikon. Angelos Baš, ed. Ljubljana: Mladinska knjiga, 271.

Nikočević, Lidija. 2012. "Kultura ili baština? Problem nematerijalnosti”. Etnološka tribina 42/35: 7-56.

P. L. 2007. "Kravji Bal v Bohinju”. Gorenjski glas, 14 September 2007: 4.

Poljak Istenič, Saša. 2005. "Festival through the Optics of Folklorism and Heritage Tourism. Case-Study of the Country Wedding in Ljubljana". In Kulturelles Erbe. Ingo Schneider et al., eds. Innsbruck: University Press, 128-153.

Poljak Istenič, Saša. 2008. “Šege in navade kot folklorizem”. Traditiones 37/2: 61-110.

Ramovš, Mirko. 2004. "Tončka Marolt”. In Slovenski etnološki leksikon. Angelos Baš, ed. Ljubljana: Mladinska knjiga, 310.

Ramovš, Mirko and Ingrid Slavec Gradišnik. 2004. "France Marolt”. In Slovenski etnološki leksikon. Angelos Baš, ed. Ljubljana: Mladinska knjiga, 309-310.

Rant, Mateja. 2009. "Živino prignali v dolino”. Gorenjski glas, 22 September 2009: 24.

Rihtman-Auguštin, Dunja. 1978. "Folklor, folklorizam i suvremena publika". Etnološka tribina 7-8/1: 21-28. 
Stanovnik, Vilma. 2006. "Vzela sta se Karolina in Rok". Gorenjski glas, 1 August 2006: 4.

Stare, Polonca. 2007. Kmečka ohcet v Bohinju [Unpublished diploma thesis]. Bled: Višja strokovna šola za gostinstvo in turizem.

Šemrl, Ljudmila. 1964. "Kmečka ohcet v Bohinju”. Turistični vestnik 12/11: 328.

Šilc, Gregor. 2010. Pomen turističnih prireditev v Bohinju [Unpublished diploma thesis]. Portorož: Fakulteta za turistične študije, Turistica, Univerza na Primorskem.

Škrjanc, Renata. 2003. "Po sedmih letih na Kmečko ohcet”. Gorenjski glas, 29 July 2003: 21.

Škrjanc, Renata. 2004. "Petdeseti Kravji bal”. Gorenjski glas, 14 September 2004: 21.

Škrjanc, Renata. 2005. "Na kmečki ohceti pa ne”. Gorenjski glas, 2 August 2005: 4.

Štruc, Katja. 2011. "Majerji, živina in 'basenga”'. Gorenjski glas, 20 September 2011: 4.

Zaplotnik, Cveto. 2008. "Priprava in raba lesa z kurjavo”. Gorenjski glas, 23 September 2008: 18.

1947-6.pdf = Zapisnik zborovanja masovnih organizacij OF, oziroma zastopnikov vseh organizacij Bohinja, 18 August 1947.

1947-8.pdf = Zapisnik seje upravnega in nadzornega odbora podružnice TDS Bohinj, 21 December 1947.

1953-1.pdf = Zapisnik VIII. rednega občnega zbora TD Bohinj, 15 March 1953.

1954-1.pdf = Zapisnik sestanka pripravljalnega odbora za kravji bal, 26 September 1954 .

1955-2.pdf = Zapisnik seje TD Bohinj, 25 December 1955.

1955-8.pdf = Zapisnik seje upravnega odbora TD Bohinj, 5 June 1955.

1955-12.pdf = Poročilo predsednika za 10. občni zbor TD Bohinj, 19 March 1955.

1955-13.pdf = Poročilo folklorne skupine za redni občni zbor TD Bohinj, Anton Ogrin, 19 March 1955.

1956-6.pdf = Zapisnik o sestanku prireditvenega odbora TD za kravji bal, 21 September 1956.

1960-3.pdf = Zapisnik 6. seje upravnega in nadzornega odbora TD Bohinj, 6 October 1960.

1961-7.pdf = Zapisnik 1. seje upravnega in nadzornega odbora TD Bohinj, 9 March 1961.

1961-15.pdf = Zapisnik seje prireditvenega, upravnega in nadzornega odbora turističnega društva Bohinj, 8 September 1961.

1961-21.pdf = Zapisnik 1. seje prireditvenega odbora TD Bohinj, 31 May 1961.

1962-5.pdf = Zapisnik seje upravnega in nadzornega odbora TD Bohinj, 28 August 1962.

1966-12.pdf = Zapisnik 3. redne seje upravnega odbora TD Bohinj, 18 November 1966.

1994-9.pdf = Program prireditev za leto 1994. 7 April 1995.

2008-5.pdf = Zapisnik 33. seje upravnega in nadzornega odbora TD Bohinj, 10 September 2008.

2008-8.pdf = Zapisnik 36. seje upravnega in nadzornega odbora TD Bohinj, 12 December 2008.

2009-5.pdf = Zapisnik 2. seje upravnega in nadzornega odbora ter disciplinskega razsodišča TD Bohinj, 20 March 2009.

2009-7.pdf = Zapisnik 4. seje upravnega odbora TD Bohinj, 27 October 2009.

2010-7.pdf = Zapisnik 12. seje upravnega odbora TD Bohinj, 9 November 2010.

2012-26.pdf = Zapisnik 26. seje upravnega in nadzornega odbora TD Bohinj, 27 November 2012. 


\title{
NEMATERIJALNA KULTURA KAO TRADICIJA: KRAVJI BAL, VASOVANJE I KMEČKA OHCET U BOHINJU
}

\begin{abstract}
SAŽETAK
Članak se bavi strategijama koje organizatori koriste kako bi potvrdili izvornost tradicije, pripisane (zamišljenoj) dugovječnosti i aspektima (ne)materijalne kulture ispaše u Alpama, bračnih običaja i lokalnog dijalekta koji se od pedesetih godina prošlog stoljeća prikazuju u priredbama Kravji bal (Kravlji bal), Vasovanje (Seoska serenada) i Kmečka ohcet (Seosko vjenčanje). Od samih su početaka organizatori nastojali postići najizvorniji prikaz tradicijske (ne)materijalne kulture, što je tijekom 1950-ih i 1960-ih dovelo do uglavnom scenskog prikaza koji je osmišljen i uz pomoć (polu)profesionalaca. S vremenom je prihvaćen i model raširen na nacionalnoj razini prema kojem se u scensku izvedbu uključuje "pravi" obred civilnog i crkvenog vjenčanja, a tekstovi koji su se izvodili su skraćeni i učinjeni zabavnijima. U većini se slučajeva smatralo da su tekstualni aspekti izvedbe ti koji pridonose njezinoj izvornosti. Tek se u posljednje vrijeme u obzir uzimaju vremenski i prostorni kontekst (ne)materijalne kulture, dok se model scenskog prikaza sve više propituje. Ipak, društveni aspekti (ne)materijalne kulture još uvijek se ostavljaju po strani, a osim toga ni na samu se izvedbu i njezin scenski prikaz ne gleda kao na nematerijalnu kulturu.
\end{abstract}

Ključne riječi: nematerijalna kultura, tradicija, izvornost, kulturni prikaz, turizam događaja 